ISSN: 1641-4713; e-ISSN: 2081-1160

DOI: https://doi.org/10.36551/2081-1160.2019.24.75-100

\title{
La Alquimista de los Sabores: Gastronomic heritage, gender, and the tourist imaginary in Mexico
}

\author{
La Alquimista de los Sabores: Patrimonio gastronómico, género \\ e imaginario turístico en México
}

Renata E. Hryciuk Institute of Ethnology and Cultural Anthropology, University of Warsaw ID ORCID: https://orcid.org/0000-0002-6740-0514

E-mail: r.hryciuk@uw.edu.pl

Recepción: 4.02.2019

Aprobación: 14.07.2019

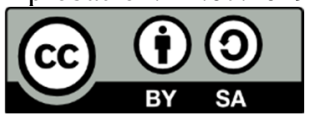

Abstract: Through multi-sited fieldwork carried out in 2011 and 2014-17 in central Oaxaca and an
analysis of secondary sources, this paper scrutinizes the rise of a culinary celebrity, Zapotec cook
Abigail Mendoza Ruíz of Teotitlán del Valle, Oaxaca, in the broader context of a Mexican cultural
politics of food as heritage. Focusing on food-related biography this essay reveals vernacular dy-
namics of heritagization of native foodways and the role renowned female cooks (cocineras) have
played in this process. I scrutinize negotiations and contestations as well as open conflicts related
to the representation of heritage, the politics and rights between different actors engaged over the
years in (re)constructing a social imagery of ethnic female cooking for the benefits of the tourism
industry, and, more broadly, state attempts at re-branding Mexico as a safe gastronomic destination.

Keywords: gastronomic heritage, gender, culinary tourism, Oaxaca, Mexico.

Resumen: A través de un trabajo de campo multi-situado realizado en 2011 y 2014-17 en la región central de Oaxaca y del análisis de fuentes secundarios, este texto analiza el surgimiento de una celebridad culinaria, la cocinera zapoteca Abigail Mendoza Ruíz de Teotitlán del Valle, Oaxaca, en el contexto más amplio de la política cultural mexicana de la comida como patrimonio. Centrarme en la biografía relacionada con la alimentación me permite revelar las dinámicas vernáculas de la patrimonialización de las prácticas alimentarias-culinarias nativas y el papel que han desempeñado en este proceso las cocineras de renombre. Escudriño las negociaciones y las disputas, así como los conflictos abiertos sobre las representaciones del patrimonio, la política y los derechos entre los 
diferentes actores que han participado a lo largo de los años en la (re)construcción de imágenes sociales de la cocina étnica femenina en beneficio de la industria del turismo y, en términos más generales, los intentos estatales de rebautizar a México como un destino gastronómico seguro.

Palabras clave: patrimonio gastronómico, género, turismo culinario, Oaxaca, México.

In the autumn of 2014, a video advertisement titled "Mexico's Gastronomy on the Move," part of the Visit Mexico campaign commissioned by the Mexico Tourism Board, was posted to social media platforms. It reflected governmental agencies' growing interest in food and foodways as potential tourism products, following the 2010 inscription of Traditional Mexican Cuisine on the UNESCO Intangible Heritage List. The video forms part of a wider government strategy of promoting heritage tourism in order to re-brand the country, bolster national pride, and contribute to Mexico's sustainable social and economic development. Supported by global players including UNESCO and the World Bank, similar cultural policies emphasizing the appeal of local food cultures in the gentrified form of gastronomy have been implemented across multiple post-revolutionary and post-conflict regions of Latin America, such as Peru and Colombia (Babb, 2010; Camacho, 2014; Matta, 2016). Emphasizing the appeal of local food cultures in a gentrified form of gastronomy is typical for the new trends in the global tourism industry, serving as a basis for today's gastro-diplomacy, its Mexican variety included (Cf. Rockower, 2012).

Mexico's international image has been deteriorating rapidly since 2006, when the government launched the so-called "war on drugs." The aforementioned promotional video was released at the height of another serious political crisis: the September 2014 kidnapping and disappearance of 43 students from the Rural Teacher's College in Ayotzinapa, Guerrero, a center of political activism against corruption and the local government's collusion with drug cartels. So far unexplained, the crime stirred the public both in Mexico and abroad, leading to social unrest, with the slogan "Ayotzinapa43" quickly becoming the symbol of the struggle against narco-politics and a permanent feature of anti-government protests. As a consequence, in the country where tourism is the third largest source of national income after oil and migrant remittances and for decades has been the principal strategy for economic and social development in many regions (Cf. Berger, Grant Wood, 2010), state tourism agencies faced the daunting task of creating persuasive media images of safe destinations despite Mexico once again making global headlines due to violence. 
The script for "Mexican Gastronomy on the Move" reflects a concept of culinary tourism that sees food as both "a destination and vehicle for tourism" (Long, 2004: 2). It primarily targets rich foreign tourists and affluent nationals, depicting Mexico as "foodies' paradise," within the safety of high-end resorts and restaurants. The aim of the video was to present the evolution of the local food culture, with the opening sentence of the voice-over commentary asking: "Did you know that Mexico's gastronomy is cultural heritage of humanity? And now it's on the move!" Although Traditional Mexican Cuisine was inscribed on the UNESCO List as an ancestral, ongoing community culture with emphasis on local, native, traditional, and feminine aspects of food heritage ${ }^{1}$, the promotional video focuses on star chefs, dishes, and ingredients presented in elite restaurant spaces. The state agencies are promoting new Mexican gastronomy as cosmopolitan, transnational, innovative, and predominantly masculine-once again, gentrified peasant cooking served to an (inter)national elite becomes an accepted form of national heritage (Pilcher, 2012; Sammells, 2014; Gálvez, 2018).

The three-minute clip features sixteen individuals: female and male chefs, most of them carefully posed, with their names and the names of their restaurant provided in captions. Among five women, the two that represent "traditional cuisine" appear at the very beginning: Carmen 'Tita' Ramírez, the founder of the El Bajío restaurant in Mexico City, and Abigail Mendoza dressed in a colorful ethnic outfit, representing the Tlamanalli restaurant in Teotitlán del Valle, Oaxaca. The latter is shown again, when the narrator mentions the pre-Hispanic roots of modern Mexican gastronomy. We see her at work, in a stylized colonial kitchen, donning ceremonial garb: the ethnic entrepreneur demonstrates embodied skills and the knowledge of traditional culinary techniques by kneeling at the Pre-Columbian grinding stone (metate) on which she is grinding chiles.

The tourism industry selectively appropriates certain elements of culture to symbolically imagine a country, region, or city in promotional campaigns (Salazar, 2012). In Mexico, the images associated with indigenous cultures and the Pre-Columbian past are exploited particularly by different actors involved in the development of heritage tourism industry. Folklorized images of indigenousness typically present young women in ethnic clothing, with characteristic hairstyles and typical artifacts (e.g. artisanal products), set against the background of historical sites, monuments, and cultural landscapes (Berger, Grant Wood, 2010).

\footnotetext{
1 https://ich.unesco.org/en/RL/traditional-mexican-cuisine-ancestral-ongoing-community-culturethe-michoacan-paradigm-00400
} 
Culinary tourism advertising (e.g. food festival posters, flyers, social media graphics and videos) also uses the images of experienced, older women, usually in the context of food preparation: selling produce at local markets, grinding ingredients on a metate, or making tortillas. These are usually anonymous representations that homogenize the experiences of native women, converting them into repositories of national tradition for the purposes of cultural tourism. Abigail Mendoza appears to be one of a handful of exceptions, as she is presented as an authentically indigenous successful entrepreneur. However, we only learn the name of her restaurant. The commercial mentions neither the ethnic group she belongs to nor the region of Mexico she represents.

The position Mendoza has managed to achieve in national gastronomic circles and her media image raise a number of questions: How to interpret her spectacular success and degree of professionalization as one among many indigenous cooks? How to explain her impressive career in a patriarchal, predominantly masculine, class and race-determined world of haute cuisine, which typically treats native female cooks as a source of knowledge and cheap-though highly skilled - labor? What political, economic and ideological goals are served by using her image to promote Mexico as a destination for cultural tourism? And, finally, for other native cooks who see culinary tourism as a chance to improve their own and their families' well-being and to engender social and economic development in their communities, what are the consequences of establishing a system of indigenous celebrities with Mendoza as its fore runner?

This text aims to answer the above questions by analyzing Mendoza's life and career. Inspired by a Carole Counihan's (2009) food-centered life history methodology, I examine Mendoza's media image, personal success, and empowerment in the context of the rise of culinary tourism and the making of gastronomic heritage in her home village, the state of Oaxaca, and in Mexico. My analysis is based on the results of multi-sited fieldwork conducted in central Oaxaca in 2011 and 2014-17, ${ }^{2}$ as well as earlier observations during regular holiday visits in the years 1999-2009. Prolonged on-location presence and participant observation, in-depth interviews with various social actors involved in the production of gastronomic heritage for the purposes of tourism, supplemented by close readings of cookbooks, ethnographic monographs, and media discourse provided material

\footnotetext{
${ }^{2}$ Fieldwork in 2011 and 2016-2017 was sponsored by Genaro Estrada grants for Mexican Studies specialists funded by the Mexican government (AMEXCID), research stays in 2014-2015 were founded by the Polish National Science Centre (DEC-2012/07/D/HS3/03814).
} 
for a thick description of the heritagization of local food cultures and the development of a culinary tourism industry in Oaxaca. ${ }^{3}$

I conducted research in the capital city and in several communities in the Central Valleys of Oaxaca, including Teotitlán del Valle. In September 2011, I interviewed Abigail Mendoza in her restaurant, along with two of her sisters (Marcelina and Rufina). I later interviewed one of her brothers in Oaxaca City. After that, I talked to the Mendoza sisters on several occasions during festivals and fairs in the state capital. I visited the community many times, including during its most important religious celebrations, Sunday market, and private family fiestas. I had meals in local eateries and restaurants (three times in Tlamanalli), and took different tourist tours to Teotitlán. I also participated in several cooking classes in El Sabor Zapoteco, a culinary school operated by Reyna Mendoza, Abigail's cousin. In total, I interviewed 14 other residents of the community: members of Mendoza's extended family as well as other people engaged in the local cultural tourism industry.

The analysis presented here contributes to feminist studies of food and foodways (Cf. McLean 2014), and the dynamically developing field of anthropologically oriented critical studies of food heritage (Brulotte, di Giovine 2014; Sammells, 2014; Camacho, 2014; Geyzen, 2015; Matta, 2016; 2019). It applies an emic approach, in line with heritage agnosticism, which, "takes people's heritage experience and beliefs seriously" (Brumann, 2014: 180). It adds to the existing body of knowledge an analysis of the ways in which indigenous women understand their relationships to food heritage. Moreover, the nature of the processes of food heritagization in contexts marked by historically determined, deeply rooted sociocultural disparities may provide an incentive to broaden the Western models of food heritage studies (see Geyzen, 2015). By considering gendered ethnicity and a more grassroots perspective of subaltern groups in the Global South this analysis expands the study of food heritage, addressing existing interconnected inequalities as well as newly emerging areas of inequality.

\footnotetext{
${ }^{3}$ During three years of fieldwork I did participant observation during dozens of regional food festivals and ferias, took part in seven food tours, 13 cooking classes and courses, and made multiple visits to regional markets, local eateries and restaurants. I conducted 125 interviews with elements of life-histories (in Spanish and English, from one to four hours long, recorded and transcribed) with native cooks, chefs, journalists, government officials, activists, market sellers, Mexican and foreign culinary tourists, tour operators, and anthropologists, among others.
} 


\section{“THE HEART OF MEXICAN GASTRONOMY"}

Located in southern Mexico, Abigail Mendoza's home state of Oaxaca is presented in tourist publicity as one of the last strongholds of authentic "deep Mexico" (Bonfil Batalla, 1996). The most indigenous and ethnically diverse therefore by extension traditional and culturally authentic, mountainous and therefore inaccessible with well-preserved biodiversity, Oaxaca boasts a rich culinary tradition associated with ritual eating during an extensive system of holidays (Gagnier, 2005; Stephen, 2005). These elements give Oaxaca the aura of a somewhat mysterious region frozen in time, a picturesque paradise for more intellectually and culturally minded travelers, including foodies (Pilcher, 2004; Kastelein, 2010).

Oaxaca's current tourist offer lives up to all of the promises of the "Mexico's Gastronomy on the move" commercial. The state's capital and the surrounding Valles Centrales region currently have rich culinary tourism offerings, from highend restaurants, stylish coffee shops and bars specializing in mezcal tasting, to eateries at town and village markets, street food, several reputable cooking schools, food festivals, gastronomic tours, shows and annual culinary festivals that promote the culinary heritage of local towns and indigenous communities After migrant remittances, tourism provides the state's next highest source of income. In recent years, throngs of tourists and food experts from the across the globe, joined by increasing numbers of affluent Mexicans with a particular interest in gastronomy, have made Oaxaca one of the hottest food travel destinations in Latin America (Pilcher, 2004; Kastelein, 2010; Brulotte, Starkman, 2014; Hryciuk, 2018). Consumers of the local cuisine also include a steadily growing number of temporary amenity migrants (snowbirds and ex-pats), and retirees from the US and Canada moving permanently to the valleys of Oaxaca. ${ }^{4}$

Two Oaxaca-based foreigners played key roles in the development of specialized culinary tourism in the late 1980s. American chef Susana Trilling, who to this day runs a cooking school at San Lorenzo Etla and authored one of the first compilations of Oaxaca's regional recipes. The publication of Seasons of My Heart: A Culinary Journey through Oaxaca, Mexico in 1999 was accompanied by a TV series running for several successive seasons on PBS. The other trailblazer was Canadian Mary Jane Gagnier, wife of the acclaimed Zapotec painter

\footnotetext{
${ }^{4}$ According to different estimates the population of mainly North American, European and Japanese ex-pats in Oaxaca may reach 20.000 in 2019 (see https://www.expatsinmexico.com and https://www.oaxacalife.com/information/oaxaca-expats/; see also Croucher, 2009)
} 
and weaver Arnulfo Mendoza and, via her marriage, sister-in-law of Abigail Mendoza. A talented businesswoman, she co-founded La Mano Mágica, one of the most important art galleries in Oaxaca City in the 1980-90s. Noting the growing interest in food among visitors to the region, she included demonstrations of local foodways as an additional attraction for tourists and collectors visiting her in-laws' weaving shops in Teotitlán. Trilling's and Gagnier's respective business endeavors brought the first specialized culinary tours to Oaxaca, accompanied by journalists and food critics. This contributed to the development of a new, dynamically emerging niche among local tourism offerings, providing the first business opportunities for native cooks and ethnic intermediaries such as Abigail Mendoza.

In 2005, North American newspapers and specialist tourist magazines recognized Oaxaca as one of the most attractive holiday destinations in the world. ${ }^{5}$ However, the tourism boom coincided with rising social conflict that culminated in internationally publicized civil unrest in 2006. The resulting political and humanitarian crisis lasted several months. One of its negative consequences was the collapse of the tourist industry in the central part of the state, which further exacerbated the animosities in the highly stratified, post-colonial society of Oaxaca (Goertzen, 2010; Garza Zepeda, 2016). The US financial crisis of 2008, followed by the swine flu panic of 2009, and the poor international image in the wake of the Mexican government's "war on drugs" (ongoing since 2006) further contributed to the deterioration of the state's image as a tourist destination. The strategic use of cultural heritage proved crucial to re-branding Oaxaca as a safe place to visit.

In 2008, typical Oaxacan food (comida típica oaxaqueña) as the expression of "a thousand-year old cultural identity" was awarded the status of "cultural intangible heritage of the state of Oaxaca" by the Congress of Oaxaca. In 2010, Traditional Mexican Cuisine was inscribed on the UNESCO Intangible Cultural Heritage list. ${ }^{6}$ The same year, renowned and influential expert on Mexican cuisine Diana Kennedy published a collection of recipes titled Oaxaca al Gusto: An Infinite Gastronomy. Soon after, the concept of gastronomic heritage (patrimonio gastronómico) began to replace the term comida típica when referring to regional

\footnotetext{
5 See: https://www.nytimes.com/2005/11/20/travel/oaxaca.html, https://www.washingtonpost.com/archive/lifestyle/travel/2005/04/17/in-oaxaca-it-takes-seven-villages/ed040220-232f4d7d-9ac4-fafb598fd2c5/?noredirect=on\&utm_term=.7d59ec50fee2

${ }^{6}$ Although the designation specifies the Michoacán paradigm it has been extended to the entire country.
} 
cuisine. Promoted by UNESCO agencies and specialized, national NGOs (among them Conservatory of Mexican Gastronomic Culture, or CCGM), the elitist concept of gastronomy has become the central element in the hegemonic discourse of Mexican heritage-making, pushing the broader understanding of food heritage-alimentary heritage that includes the alimentary system, food culture, and that emphasizes food security and sovereignty of a given group - to the margins.

It is important to bear in mind the broader socio-political context in which local gastronomy flourishes for the benefit of international tourism. Oaxaca is currently the poorest and most socially and economically stratified among Mexican states, with multiple areas of extreme social marginalization. ${ }^{7}$ It has high rates of migration associated with the collapse of agriculture following Mexico's joining of NAFTA in 1994, natural disasters, conflicts over land and access to water, lack of food security, and other forms of structural violence (Stephen, 2007; 2013). Socio-economic transformations of the recent decades have significantly altered consumer behaviors and eating habits; the everyday diet even in the most remote communities features more processed food, leading to higher malnutrition and diabetes rates (González, 2014).

\section{NEW YORK TIMES' REVIEW AND THE RISE OF CULINARY CELEBRITY}

In 1993, New York Times food critic Molly O'Neill put Tlamanalli on her personal list of the ten best restaurants in the world. Back then, the establishment that inspired the American journalist's enthusiasm operated in the Mendoza family's spacious weaving workshop, having evolved out of cooking demonstrations for North American customers. Mendoza offered her foreign patrons "authentic Zapotec food", prepared using ancestral cooking methods and fresh, local ingredients. At Tlamanalli, dishes traditionally served during an elaborate system of fiestas were served in the familiar, presumably safe and hygienic space of a restaurant. Here foreign food adventurers enjoyed "authentic, expertly prepared, and beautifully served Oaxacan cuisine" (Friedensolm, 2001: 168) framed in the conventions of the Western menu: aperitif and appetizer, soup, main course (one of the famous local moles), dessert and coffee, so that the foreign, ritual and exotic food became domesticated, familiar, and even delicious for foreign tourists (Long, 2004).

\footnotetext{
${ }^{7}$ According to the Mexican National Institute of Statistics and Geography in 2015 the state of Oaxaca had a population of $3.967,889,67 \%$ of whom lived in poverty, $28 \%$ of whom in extreme poverty. Cf. http://www.coneval.org.mx/Medicion/Paginas/PobrezaInicio.as
} 
A good illustration here would be the account of one of many American food adventurers, Doris Friedensolm, who guided by positive reviews in the US press picked the restaurant in Teotitlán to sample Oaxaca cuisine during her visit to the region in 1996: "Tlamanalli, the restaurant, named for the Zapotec god of food, occupies a handsome, newly built, brick building about a block from the center of town. The only identifier is a small bronze plaque near the door, a plaque so discreet as to be almost invisible. Passing through a twenty-foot vaulted, doorway, Nancy and I enter a vast, bright, barnlike space. Tall trees and lush, semitropical plantings divide the restaurant proper from a "gallery" where carpets woven by the renowned Mendoza brothers are displayed (...) Abigail Mendoza, the owner of Tlamanalli, is a sister of the weavers; her indispensable collaborators in cooking and serving are her five sisters. When we visit, four of them are in the restaurant, all short, smooth-skinned women, their coloring a honey-orangebrown, with waist-length, shiny black hair braided with colored wool. They wear long, brightly printed cotton dresses covered with white aprons. The sisters' traditional Zapotec appearance contrasts sharply with the low-key, modern style of furnishings: blond wooden chairs, blond square tables, pale pink tablecloths, and smart, tiny vases filled with homegrown roses - a "today" look popularized by Martha Stewart, the Gap, and the Pottery Barn (Friedensolm, 2001: 169). The famous festive dish "mole negro" selected by the author as her main course is also served European style, on "a large white plate accompanied only by a small portion of white rice dotted with cubes of carrot and zucchini" (Friedensolm, 2001: 170).

With the support of her family, the Zapotec cook played an important role at the initial stages of the development of organized culinary tourism in Oaxaca. The restaurant's international renown attracted the attention of Mexican cuisine experts, both national and foreigner alike. With the help of her Canadian sisterin-law, Mendoza started a working relationship with, among others, Marylin Tausend's company Culinary Adventures. Soon after, the Mendoza sisters-led by Abigail-became experts in organizing festive food tastings and culinary demonstrations, accompanied by explanations of the ritual significance of each dish for North American "foodies" (Pilcher, 2004).

The financial success of their commercialization of authentic foodways and textile sales enabled the Mendoza family to construct an impressive building in the center of the community, where the restaurant moved in 1997. The success of Tlamanalli came at the time when indigenous cuisine was perceived by many as authentically Mexican but lacking culinary artistry. The officially acknowledged, 
state-promoted gastronomic trend was still New Mexican Cuisine (nueva cocina mexicana) and foreign-born, middle-class chefs, mostly male, combined French cooking techniques and local ingredients to produce gentrified peasant cooking for an (inter)national elite (Pilcher, 2012). Indigenous women were employed at the new restaurants either as mayoras, experts in the preparation of traditional dishes, such as mole and tamales, or as kitchen help tasked with the manual production of tortillas.

Mendoza's unquestionable talent and charisma, combined with her connections in international gastronomic circles, experience, and polish made her a sought-after culinary instructor, invited by American and European cooking schools, food festivals, and a frequent subject of press reports and interviews. Her international recognition prompted the local Ministry of Tourism in 2005 to appoint her as the representative of Oaxaca in the delegation that presented the Mexican Traditional Cuisine proposal before UNESCO (Núñez Miranda, 2011). The presence of indigenous female cooks validated the creations of male chefs from famous Mexican restaurants. The two culinary events just mentioned, the review in the New York Times and involvement in Mexico's application for intangible heritage status for its cuisine, thus became foundational moments for Abigail Mendoza's career and her later prominence in the world of haute traditional cuisine (Sammells, 2014).

What, then, were Abigail Mendoza's beginnings? The most celebrated traditional cook of today was born in 1960 in Teotitlán del Valle, the third of ten children, and the first daughter in a family of local weavers. Her childhood and adolescence coincided with a period of the town's rapid development, associated with the growth of production and sales of woven wool handicrafts, as well as increasing transnational mobility This led to the notable rise in affluence of some families in the community, and, consequently, widening social stratification (see Stephen, 2005; Woods, 2008). Anthropologist Lynn Stephen describes Mendoza's age cohort as a "bridge generation" (Stephen, 2005: 63) that reflects ideas of both younger and older generations of indigenous women in Teotitlán. In the patriarchal community that valued men over women, girls of the generation were often denied the right to education, despite existing legal regulations. They experienced various gender-related limitations, even including their mobility within the community. Once married, they lost even more independence, while assuming additional burdens associated with participation in the system of religious and family fiestas (Stephen, 2005: 90). 
Like many other women of her generation, Mendoza completed only few years of primary school and learned rudimentary Spanish growing up. Before the 1990s, she rarely traveled outside her native village. Her labor- performing household chores, cooking, taking care of younger siblings, working at the weaving workshop, and her involvement in the preparation of ritual dishes during fiestas-was indispensable for the proper functioning and well-being of her family, as well as for social reproduction within the community. However, unlike most of her peers, Abigail never married and had no children. Over time, with her family`s support and her own determination and ability to take advantage of favorable opportunities, she managed to transform the vast knowledge of local foodways and embodied cooking skills still common in her generation into a lucrative business opportunity (Núñez Miranda, 2011).

In press and personal interviews, Mendoza usually describes the early days of her career in terms of individual life choices supported by her family, especially its male members. She invariably emphasizes the role and the support of her father, a capable weaver, former mayor of Teotitlán, and respected member of the community. He backed the public activity of his daughter even when it conflicted with commonly held gender norms of behavior, in which unmarried women are not accorded full status community adults (Stephen, 2005). Mendoza quickly progressed from cooking in the household (for her family and workers employed in the workshop) and regular participation in collective cooking during fiestas to preparing gourmet regional dishes in a restaurant that courted clients from outside her hometown. To explain such a rapid advancement from local cooking to preparing international haute cuisine, she interprets her career path in terms of individual agency: cooking is her passion and her life choice that gradually became her profession (Núñez Miranda, 2011).

In interviews, she emphasizes her interest in cooking from a very young age. As a small girl, she already wanted to use the metate and prepare tortillas. These difficult, physically demanding, and tedious everyday chores were at that time the main element of indigenous women's socialization. The ability to successfully prepare staple foods, especially tortillas, was the test of a woman's adulthood and a traditional mark of prestige (Stephen, 2005; Núñez Miranda, 2011). Due to socio-cultural changes in recent decades, making tortillas from scratch came to be treated as an onerous chore, even resisted by some women (Stephen, 2005; Christie, 2008; Wynne, 2015). Supposedly it was passion and personal ambition that motivated Mendoza to learn the preparation of ritual meals served at religious and family fiestas, rather than the community and family custom that 
tasked the eldest daughters and young women with the duty of taking up collective cooking. In Teotitlán, as in many other indigenous communities throughout Oaxaca and Mexico more generally, the intergenerational transmission of culinary knowledge and the division of work during ritual cooking is very clearly defined and hierarchical. Young women begin with the most basic but also the toughest manual labor: hours of grinding ingredients on metates and making tortillas. With age they become more experienced, and if they marry they graduate to other activities. Commonly, elderly women called comideras are considered to be the indisputable kitchen experts. Senior cooks with the most advanced skills and knowledge, they also command the most prestige among their peers. They are veritable "native chefs," directing the work of the entire group during fiestas (Gagnier, 2005; Christie, 2008). As a young woman, Mendoza took part in the preparation of food for religious fiestas sponsored by her parents, ceremonial wedding receptions for her siblings, and lavish meals associated with her father's offices. She then honed her skills overtime under the tutelage of an established comidera, with the menu of her prospective restaurant already in mind (Núñez Miranda, 2011).

In her often-recounted story of the beginnings of Tlamanalli, including in her autobiography (Núñez Miranda, 2011), Mendoza creates the image of a selfmade woman achieving her goals with her talent, hard work, and perseverance. She downplays or completely omits her family's relatively privileged status within the community, the opportune historical moment, and the socio-economic context in which her restaurant was able to flourish: the growth of a craft food industry attracting tourists and her brother's marriage to an up-and-coming Canadian businesswoman who provided knowledge of North American models of consumption, and the first contacts with foreign press and culinary circles. At the time, the competition among local merchant and artisan families was particularly fierce (Wood, 2008); adding the element of culinary tourism improved the attractiveness of the family weaving shop so dramatically that Mendoza's cooking talents, contrary to tradition, could be presented in a culturally foreign space of a restaurant. With time, she was able to garner personal prestige in the individualistic and highly masculine field of gastronomy.

Careful analysis of the circumstances surrounding the establishment of Tlamanalli and the narratives of Mendoza's success clearly reveals the tensions, competition, and conflicts associated with the process of heritagization of local foodways for the purposes of cultural tourism (Brulotte, di Giovine, 2014). The most glaring omission in the food-centered life history of the Mexican cook is the 
role her Canadian sister-in-law played in the establishment of the restaurant and its subsequent success. In fact, this is a case of mutual descriptive omission, since in the memoirs about her life in Teotitlán, Gagnier fails to even mention Tlamanalli, or the special role she played in the career development of her sister-in-law. The University of New Mexico Press published Mary Jane Gagnier de Mendoza's book Oaxaca Celebration: Family, Food and Fiestas in Teotitlan in 2005; the Spanish translation was published by the prestigious Artes de México CONACULTA series only two years later. Both editions are high quality, printed on glossy paper, and contain many photographs. Through the lens of her cultural adjustment and daily life in the pueblo, Gagnier describes a cycle of religious and family holidays, with particular emphasis on collective cooking and ritual commensality. The comideras' role in the reproduction of local culinary culture is stressed; the volume contains photographs of preeminent female cooks and two recipes for the pueblo's typical dishes. There is not a single mention in the book of Abigail Mendoza or the role she played in the preparation of fiestas described in the account (for example, the opulent reception for Gagnier's wedding in the community), and she only appears in one group photo with other family members.

The residents of Oaxaca I interviewed spoke of the book as an agile move by the foreign businesswoman. Already an established expert on the local handicraft and art market, at the turn of the twenty-first century Gagnier made a foray into the new segment of the tourist and hospitality industry, opening a bed and breakfast in Teotitlán. Enjoying almost a decade of success, "Casa Sagrada" served indigenous and international dishes and offered, among other things, cooking lessons. Abigail's younger cousin Reyna Mendoza taught the classes ${ }^{8}$. A picture of her with her mother Doña Antonia appears in Gagnier's book, next to praises of her talent and artful cooking. Publishing an ethnographic account of the local festive life legitimized Gagnier in the eyes of her potential clients as an expert totally immersed in the culture of the Zapotec pueblo. It also proved to be a great marketing tool during the pre-2006 tourist boom, amid growing competition in the culinary tourism market. The two women have so carefully avoided mentioning one another in their accounts of personal and professional life that a reader unacquainted with local gastro-politics would need an in-depth investigation to reconstruct their long-term relationship and its role in making Teotitlán such a vital center for culinary tourism. The immediate cause of this mutual lack of acknowledgement in the gastronomic history of Oaxaca, besides direct

\footnotetext{
${ }^{8}$ See: http://cookingclasseselsaborzapoteco.blogspot.com/p/meet-reyna.html
} 
business competition, was the family conflict that culminated in a divorce and the dissolution of the common business ventures, including the closing of "Casa Sagrada." As far as the representation of Teotitlan's food heritage is concerned, it seems that it is Gagnier who emerged victorious: her book published both in English and Spanish (and not Mendoza's autobiography published several years later in Spanish only) is better known and more widely available. Gagnier's account is likely the introduction that potential patrons of Tlamanalli have to the intricacies of the pueblo's ceremonial life and the local culinary culture. ${ }^{9}$

\section{THE FESTIVAL: EMERGING NEW CULINARY ELITES}

On 8 September 2011, in the library of Oaxaca's Centro Cultural Santo Domingo, a successful launch of Abigail Mendoza's biography entitled DISHDAA'W. La palabra se entreteje en la comida infinita. La Vida de Abigail Mendoza took place, as part of the third El Saber del Sabor (SS) food festival. The event was attended by her co-author, Concepción Sylvia Núñez Miranda, the director of the Harp Helú foundation, María Isabel Grañén Porrúa, and Alejandro de Ávila, a member of the PRO-OAX foundation, director of the local ethnobotanical garden, and an Oaxacan public intellectual. Members of the audience included Mendoza's family and friends, food experts, and journalists covering the festival, chefs, owners of cooking schools and restaurants, as well as several anthropologists researching the topic. During the presentation, there was a brief discussion of why the book had been written, its significance in documenting Oaxaca's food culture, and the fundamental role of female indigenous cooks for the conservation of Mexico's culinary culture and, more broadly, the country's cultural heritage.

Unlike in other states (Cf. Stanford, 2012), in Oaxaca it was the NGOs dealing with cultural heritage that began supporting and promoting indigenous and mestizo female cooks, providing them with dedicated spaces during events such as the SS Festival. The 2011 event was special in that respect, with its motto citing the "social responsibility of gastronomy." The event opened with a buffet dinner in the Ethnobotanical Garden, with renowned cooks representing eight regions serving their local dishes. Some were selected to work with famous chefs invited to the festival to prepare special dinners at high-end restaurants. Intended as an opportunity to exchange knowledge and work together, the arrangement resulted

\footnotetext{
${ }^{9}$ The book is mentioned and recommended in other publications aimed at "romantic ethnic tourists" heading to Oaxaca e.g. Goertzen, 2010.
} 
in the chefs learning new cooking techniques, ingredients and local recipes, with only very few female cooks benefiting by gaining connections to the world of high-end gastronomy ${ }^{10}$. The general impression was that, once again, the cocineras were treated as a highly skilled, ethnic workforce. The festival poster perfectly illustrated this inequality: photographs of unnamed indigenous women provide a backdrop for the images of famous male chefs.

The slogans of subsequent editions of the festival no longer evoked the social responsibility of business. The participation of female cooks was limited to the opening dinner, itself moved to one of the town's colonial squares, and to subsidiary open-air events away from the town center in traditional neighborhoods or pueblos. From its first iteration, the festival has been one of the main spaces of gastronomic heritage making. The regional dishes presented by the female cooks are supposedly a testament to the diversity and culinary wealth of the state, while the goal of the organizers has been to put Oaxaca (read several newly-established upscale restaurants) on the map of Mexico's gastronomic hot destinations, and to attract high-end culinary tourism. The event's protagonists have always been the invited star chefs from other states or from abroad, and the group of local, male culinary celebrities representing the new Oaxacan cuisine (cocina de autor).

From its inception, the SS Festival has promoted Oaxacan cuisines in accordance with the Conservatory of Mexican Gastronomic Culture (CCGM) instructions: to rescue, safeguard, and protect intangible food heritage while promoting new and innovative trends, in order to guarantee the continuity of culinary patrimony and maintain the identity and proper character of Mexican cuisine for future generations. ${ }^{11}$ The way to achieve these goals is first and foremost to mobilize the efforts and work of so-called traditional cooks (cocineras tradicionales), indigenous and non-indigenous experts in local foodways. In Oaxaca, local CCGM delegates have organized groups of women for the festival, as well as for cooking demonstrations for students and culinary experts, and events and campaigns that promote the state's cuisines at tourism trade fairs, festivals and demonstrations in other regions of Mexico and abroad. For several years, there have been top-down efforts to establish a coherent representation of cocineras and to create an association. Regular meetings led by one of the delegates were

\footnotetext{
${ }^{10}$ Participation in the preparation of the festival dinner at the El Origen restaurant with chef Rodolfo Castellanos launched the fast-moving career of Ix-chel Ornelas, a nutritionist by education who operated a restaurant in Tlaxiaco in the La Mixteca region and later went on to become a finalist in the 2017 edition of Master Chef Mexico and a CCGM delegate. Cf. http://foodandtravel.mx/ixchelornelas-el-talisman-de-confiar-en-si-mismo/

${ }^{11} \mathrm{http}$ ://www.ccgm.mx/ccgm/quienes-somos/
} 
convened for some time, but to no avail. Groups of female cooks are mobilized, often quite spontaneously, for specific events, but their composition keeps changing. ${ }^{12}$

If the cooks themselves recognize the need for support for their activities and the promotion of Oaxaca as a location with a unique culinary potential, why have the attempts to establish a group representing Oaxaca's traditional gastronomy met with such resistance? Several explanations appeared in my interviews. First, the heritage category of cocinera tradicional — based on the role and image of women in indigenous foodways of the Purépecha group from the state of Michoacán (the culinary case study inscribed on UNESCO's list) — proved highly controversial. In culturally and culinary heterogeneous Oaxaca, the term cocinera tradicional applies not only to cooks in indigenous communities. Here, it may denote older experts in community cuisine, who enjoy high prestige, such as the comideras from Teotitlán; champions of regional, ritual fiesta cooking in Zapotec communities of the Isthmus of Tehuantepec; cooks in traditional urban neighborhoods, as well as indigenous and non-indigenous chefs running established regional restaurants in Oaxaca City. Furthermore, most of the women I interviewed vehemently opposed the process of creating elites within haute traditional cuisine (Cf. Stanford, 2012; Sammells, 2014) by anointing certain female cooks as master cooks while marginalizing and exploiting the work of others. In the actual Oaxacan context, this top-down category is perceived as too homogenizing, occluding class, race, spatial, and generational differences present in traditional cooking. Many women do not identify with it, and openly resist the heritage-making discourse of the CCGM that seeks to place them in this rigid category and enforce additional activities for the preservation of local culinary heritage. Some of my interviewees directly criticized CCGM for promoting trends that modernize traditional regional cuisine in order to cater to the needs of what they perceived as elitist culinary tourism.

The ongoing privatization of food heritage by a small group of well-connected individuals for the purposes of elite culinary events and high-end restaurants also incites resistance against participation in a group of cooks working at the SS Festival. For example, some of my interviewees questioned the cultural competence of the SS Festival's organizers, who come from urban middle and upper-middle classes, in dealing with traditional foodways. Most women also

${ }^{12}$ Eventually, the association (Asociación de Cocineras Tradicionales de Oaxaca) was registered by the organizers of the SS festival in 2017 with the CCGM delegate Celia Florian as its president. 
criticized the gastronomic clientelism dominating the scene: the standing of a given female cook and her access to prestigious events does not solely depend on her skills and knowledge of regional cuisines, but rather on her socio-economic status and connections with state officials, NGOs, and food experts (including CCGM delegates), as well as whether her skills and image may be exploited for commercial and promotional goals at a particular time.

Given her prominence in Mexican haute traditional cuisine, it would seem that Abigail Mendoza would play the leading role in the group of cooks gathered for the SS Festival. However, her position of traditional master cook, granted by CCGM, proved to be quite ambivalent. Mendoza was not invited to prepare special dinners at the 2011 SS Festival nor was her restaurant a venue for any of the festival's events. For years she was only invited to take part as one among many other cooks preparing the opening dinner, an invitation she often rejected citing other pressing commitments: preparations for visits abroad, shooting television programs, or family obligations. She never took part in the organizing meetings of the group of cocineras or in the dinners organized by other well-known local cooks. For someone who in her autobiography and interviews complains about the lack of support for traditional gastronomy, Mendoza appeared to demonstrate little solidarity and willingness to cooperate with other women.

Meanwhile, as Oaxaca climbed the rankings of gastronomic tourist destinations, the demand for experienced female cooks who would be both experts and skillful promoters representing the state at events in Mexico and abroad has grown. The restaurants of other traditional cooks specializing in regional cuisine have gained national recognition. As a result, a strong group of locally respected cooks have emerged. They pose serious competition for Mendoza, as evidenced by the choice of culinary celebrities representing Oaxaca during the December 2014 promotion of Mexican cuisine at the Vatican. The delegation included chef Alejandro Ruiz of Casa Oaxaca restaurant, the host of the SS Festival, representing the cuisines of the Central Valleys region and Deyanira Aquino, the owner of La Teca restaurant and an acclaimed expert on the Zapotec cuisine of Isthmus of Tehuantepec region. A charismatic indigenous cook wearing spectacular regional outfits, she was generally regarded as an appropriate representative of the state.

Tracing Mendoza's professional trajectory after 2006 shows how capable she has become in shaping her own career by negotiating her position with key actors: ministry officials, foundation representatives and organizers of food events. She picks only those events and spaces that she deems appropriate and prestigious enough for demonstrating her skills and knowledge. Her status as the 
country's most important traditional cook is even stronger today: Mendoza, the authentically ethnic Zapotec cook is today a living brand representing Mexico at the most important culinary events in the world, appearing in commercials, and receiving the country's most prestigious awards ${ }^{13}$. In 2014 she won the Molcajete de Plata Award presented jointly by Zona Rosa Gourmet Association, the Mexican Academy of Gastronomy, and the Entrepreneur's Club in recognition of her achievements in gastronomy. To celebrate this occasion, she organized a reception for women of particular prominence in Oaxacan gastronomy in her family home in Teotitlán. Contrary to the expectations of some of the participants I interviewed, this event did not lead to the consolidation of the local group of cooks. Instead, it symbolically strengthened Mendoza's position as the model traditional cook in her native Oaxaca.

This development translated to the Mendoza's role in the 2015 SS Festival. Two Oaxacan women received awards: Mendoza received a special tribute in recognition of lifetime achievement in the promotion of traditional Mexican cuisine while Ix-chel Ornelas, from the Mixteca region, was named the up-and-coming talent of Oaxaca's traditional cuisine. The festival organizers capitalized on Mendoza's rising status and commodified image to elevate the prestige of their event even further, while emphasizing differences and fueling the conflicts among the rest of the local female cooks. At the opening dinner, Mendoza was the guest of honor, together with family and friends occupying a table at a central part of the square. She neither served her dishes nor visited the stands of the other cooks to greet them (felt by some a serious courtesy violation), instead posing for photographs and accepting congratulations. This was duly noticed by other cooks, who-as always, poorly paid and mistreated - felt ignored and again exploited as cheap labor. Some of the cooks expressed their dissatisfaction by not attending the event and sending their assistants to serve the food instead; others withdrew from the festival. Press and social media coverage proudly praised the achievements of the Zapotec cook, her international recognition, and the prominence she had achieved in Mexican gastronomy, emphasizing the benefits of that fact for the promotion of Oaxaca. However, others saw the way Abigail Mendoza was positioned in that year's festival as a telling example of the negative processes associated with the heritagization of local food cultures: individualization, the

\footnotetext{
${ }^{13}$ In 2019 Abigail Mendoza was celebrated by both Mexican and Spanish press. In October she featured on the cover of Vogue Mexico $20^{\text {th }}$ anniversary edition dedicated to the outstanding women of the country and in December her life and culinary career was presented in the article published in El Pais Semanal. Cf. https://elpais.com/elpais/2019/12/16/eps/1576515984_369544.html
} 
appropriation and commodification of shared, communal heritage for private benefit, unhealthy competition, unwillingness to work together, and lack of solidarity with other cooks. Although Mendoza's career conforms with the vernacular understanding of gastronomic heritage based on the system of culinary celebrities, she was only symbolically accepted in this elite group in 2015, once her image became one of the key elements of the national brand as the face of state-sponsored campaigns promoting traditional Mexican cuisine 'on the move'.

\section{EMPOWERED INDIGENOUS MASTER COOK}

As part of the celebrations commemorating the founding of the city of Oaxaca on 24-25 April 2017, the First Grand Meeting of Oaxaca's Traditional Cooks was organized by the municipal authorities in one of the capital's main squares. This introduced the practice - already well-established in other statesof promoting cultural tourism through festivals dedicated to the so-called haute traditional cuisine and its protagonists, traditional cooks. A report from the event on the CCGM website stresses the diverse culinary traditions of the state, as represented by dishes from eight regions prepared by over 50 invited cooks, emphasizing flavors, ingredients, and the intergenerational transmission of knowledge. The text is illustrated with a poster for the event showing an unnamed indigenous woman making tortillas (in fact a well-known cook Marcelina Sánchez) ${ }^{14}$ and two photographs: one of the event's organizer, the CCGM delegate Celia Florian, with a caption explaining that she is a "traditional cook and owner of the 15 Letras restaurant in Oaxaca," and a portrait of one of the guests of honor, Abigail Mendoza, with her sisters Rosario and Marcelina. This photo is also without a caption. Is it because the Zapotec cook is so well known in the Mexican culinary circles? Or, does the note in fact reflect the existing hierarchies in the local culinary tourism industry, where the women who are model traditional cooks, culinary celebrities included, are pushed aside by the rising gastronomic stars, in this case a non-indigenous cook with a highly flexible identity? Depending on the circumstances and audience, Florian presents herself as a traditional cook, chef, food expert, educator, successful businesswoman, CCGM delegate, or a Slow

\footnotetext{
${ }^{14}$ Sánchez has often represented Oaxaca in recent years at events such as the opening dinner of the SS Festival, the World Forum of Mexican Gastronomy, and The National Meeting of Traditional Cuisine. Sánchez is a subsistence farmer, selling her surplus produce at the La Merced market in Oaxaca, and is famous for her tortillas of a local variety (tlayuda). Her farm in San Juan Teitipac in the Valles Centrales region is used by CCGM delegates as a destination for culinary tours for Mexican and foreign food experts visiting the state.
} 
Food advocate, effectively building up the status of her family restaurant within the framework of traditional Mexican gastronomy. ${ }^{15}$

Despite fierce competition, Mendoza's stature in haute traditional cuisine keeps getting stronger. In 2015, she was invited to be a judge in the first episode of the Mexican version of Master Chef. The Zapotec master cook "afforded herself the luxury" (Ella se dio el lujo de rechazar ser parte de Master Chef as one headline put it) of rejecting the invitation. Moreover, she used her authority to criticize the program for essentially failing to promote Mexican cuisine, which she understands to be primarily regional and traditional (comida típica) - the one whose authenticity she has been defending for years. ${ }^{16}$ That same year Mendoza accepted another invitation, this time to take part in the Discovery Channel's "Celebrating Mexico" campaign, where she appeared as the ambassador of traditional Mexican cuisine. The only indigenous, female cook celebrated in the three episodes of the program to date stars in a two-minute clip in Spanish, shot in her hometown of Teotitlán del Valle in three contexts: in the field against the background of maize, in her restaurant preparing dishes and weaving, and at the local market. When introducing herself, Mendoza emphasizes the connection between traditional food and local, regional, and national identity, as exemplified by Zapotec cuisine. Significantly, in a community famous for its extensive system of fiestas, where women cooperate in preparation of ritual meals, where conviviality constitutes a crucial part of community life, and many families still engage collectively in subsistence farming, Mendoza appears alone, as a celebrity cook, indigenous entrepreneur, and restaurant owner abstracted from the broader sociocultural context of the Zapotec community. Additionally, the narrative she creates stresses the importance of fresh, endemic ingredients from the local market, rather than the wider alimentary system (milpa) from which they originate, reflecting the logic of a de-politicized gastronomic heritage. In the program, milpa becomes a backdrop for gastronomy. And it is by no means an isolated case: Mendoza's statements, interviews, and even the cover of her biography, are supplemented by posed photographs, stylized portraits of a culinary celebrity (sometimes flanked by her sisters), rather than images of a cook taking active part in the reproduction of community foodways.

\footnotetext{
15 The restaurant managed by Florian, Las 15 Letras, grew out of a small eatery (comedor) that offered traditional food (Cf. Friedensolm, 2001) into a trendy restaurant serving haute traditional cuisine, ranked along with Deyanira Aquino's La Teca and Tlamanalli on the list of 120 best restaurants in Mexico in 2016, 2017, 2018 and 2019 (by Culinaria Mexicana, www.culinariamexicana.com.mx).

${ }^{16} \mathrm{http} / / /$ old.nvinoticias.com/oaxaca/cultura/artes/307694-oaxaquena-que-rechazo-master-chef
} 
Abigail Mendoza represents a somewhat ambivalent figure in her home community. Without a doubt, her success helped the community recognize the potential for commercialization of the local cuisine. As an unmarried womanentrepreneur, and today the head of her family, she has overcome many genderbased limitations, from shopping alone at the market to traveling abroad, and revealed alternative sources of prestige for indigenous women. In recent years the village saw the emergence of other restaurants and eateries, a cooking school, and gastronomic demonstrations for cultural tourists at many textile workshops. As a result, a strong culinary representation of Teotitlán has formed. On the other hand, Mendoza is often criticized by inhabitants of the community for her symbolic appropriation and exploitation of local culinary heritage in the service of her personal career and improved economic status of her family. This is made even more poignant by locally entrenched differences and class conflicts associated with the development of handicrafts and tourism in the recent decades (Stephen, 2005; Wood, 2008).

Some of my interviewees from Teotitlán even claimed that Abigail Mendoza cannot be considered a full-fledged traditional cook because for years she has not been taking part in the preparation of fiestas and, by extension, the ritual life of the community. Among her harshest critics, she is said not to perform her kin obligations properly, as she is divorced from relationships based on reciprocity and no longer participates in the collective reproduction and preservation of community's culinary heritage (Cf. Stanford, 2012). Meanwhile, the truly respected, legitimate and undisputed experts on Teotitlan's foodways, elderly and often monolingual Zapotec comideras, rarely if ever represent the local food heritage outside their community.

\section{LA AlQUimista DE LOS SABORES}

Abigail Mendoza's commodified image today constitutes one of the key elements in the hegemonic discourse of gastronomic heritage in Mexico, conveniently consistent with the currently promoted model of indigenous womanhood. The Zapotec woman, the showcased traditional cook, and successful gastronomic entrepreneur has become the exemplar promoted by CCGM for other indigenous women. Her image strongly resonates with two dominant ideological frames: 1) that of neoliberal multiculturalism that views ethnicity as a source of social and cultural capital and cultural diversity as an economic asset or commodity in a global market (Kymlicka, 2013: 110), and 2) the neoliberal frame of women's 
empowerment, which forms the current foundation of development and aid programs aimed at indigenous women in Mexico (Hryciuk, 2017). In an interview published by the Oaxacan magazine "Women" in 2014 Mendoza firmly states, "I am proud of being one hundred per cent Indian, of representing our race, our roots. I feel proud and content, fulfilled; as my father would say, there is nothing you cannot achieve, if you want something, you can achieve it - all it takes is hard work, belief, and respect" (Martínez de Aguilar, 2014: 31). In fact, the example of an empowered and successful gastronomic entrepreneur who comes from an elite indigenous family, freely travelling the world, is extremely difficult for most indigenous cooks in the poorest state of the country to emulate. Its persistent promotion may be interpreted as a sign of symbolic violence on the part of neoliberal heritage institutions like the CCGM, leading to tensions and ruptures, but at the same time prompting the emergence of alternative discourses and representations of gendered food heritage in Oaxaca.

The Mexican middle and upper classes, who, for the last couple of decades, have been increasingly engaging in domestic culinary tourism, approve of this reconstruction of the social imagery of ethnic female cooks, and broader state attempts to re-brand Mexico as a safe gastronomic destination. The dominant factor here is pride in the way Mendoza has represented Mexican culinary heritage abroad. Moreover, the exemplary life-history of the indigenous self-made woman provides a welcome alternative to the tales of sweeping poverty, drug-related crimes, and the rising wave of murders of women (feminicidios) throughout the country. It is, as one website puts it, "an enclave of peace among the general savagery...the biography of Abigail Mendoza can help us understand Oaxaca through the lives of women like her, while offering us comfort in these difficult times, since there will always be something to prod us in the direction of hope and seeing our dreams accomplished." ${ }^{\prime 17}$ Additionally, the figure of the celebrated indigenous cook provides a perfect and useful illustration of the tourist imaginary (Salazar, 2012) of Oaxaca as Bonfil Batalla's “deep Mexico:" a picturesque, magical, remote, and surreal enchanting otherness (Wood, 2008; Kastelein, 2010; Brulotte, 2012). The actors engaged in the making of local food heritage eagerly reproduce that imaginary. The introduction to Mendoza's biography, penned by the director of the Harp Helú foundation, includes the following passage: "Tlamanalli is the place where Abigail Mendoza Ruíz, the alchemist of flavors, seduces good food devotees, taking them on a journey through the world of Zapotec

\footnotetext{
${ }^{17} \mathrm{http}: / /$ caracolasfem.blogspot.mx/2011/09/mujeres-y-politica-abigail-mendoza-un.html
} 
traditions, beliefs, and rituals...Abigail's artistry transcends the recipe, her richness is herself, her manner of speaking, her outlook on life, her dazzling smile and colorful braids, the way she moves that gives additional twinkle to her golden earrings" (Núñez Miranda, 2011: 11). The mechanisms of othering the indigenous elements of culture still seem to be powerfully entrenched among Mexico's intellectual elites, regardless of political affiliation. Thus, we read the following in the left-leaning daily La Jornada: "Abigail Mendoza is glowing, a smile never leaving her lips. Anyone in her vicinity is enchanted by her aura: you want to listen forever to her stories about cooking, which border on the artistic. From her story, as if from a novel, we learn that she was chosen by the Zapotec gods to pass on the Pre-Hispanic, culinary heritage of her ancestors." ${ }^{18}$. Portraying the expert in haute traditional cuisine as a "Zapotecan fairy" (un hada zapoteca), a kitchen alchemist (una alquimista en la cocina), the shaman of flavor (la chamana de sabores) is a discursive move that helps transform the previously despised, unsavory, immoral, traditional peasant, indigenous food into a culturally acceptable haute traditional cuisine (Pilcher, 2012). A meal consisting of dishes typical of the native cycle of fiestas and holidays, eaten in the appropriate space of a multiple award-winning and celebrated restaurant can also be used to build or confirm social distinction. Interaction with a smiling, pleasant, and charismatic cook can provide guests with unforgettable experiences with almost therapeutic effects. After all, Oaxaca as a place to alleviate the anxiety of the members of the Mexican upper class is the latest idea in the re-branding and promotion of the state.

In the spring of 2017, a promotional video prepared by the media platform Cultura Colectiva and addressed to the middle class exhausted by its urban lifestyle, appeared on social media. The following message accompanies a rapid sequence of shots showing local attractions: "Tired, sore, feeling low? What you need is Oaxaca! - an addictive antidepressant, the colors, shapes, smells, flavors - there are so many of them here! Coming to Oaxaca is not a question of transport, it is a state of mind, to experience its traditions, enjoy its sacred food, fall in love with its azures and get to know the locals. If someone asks, where Oaxaca is the answer is very simple - Oaxaca is where the heart is!" Fittingly, the clip would

\footnotetext{
18 “Abigail Mendoza es un ser luminoso. En su rostro la sonrisa es permanente. Quien se acerca a ella cae atrapado por la magia de su aura; dan ganas de escucharla todo el tiempo cuando comienza a relatar los secretos de su gastronomía, casi artística. Al conocer su historia se sabe que, como en una historia de ficción, los dioses zapotecos la eligieron para transmitir su idiosincrasia culinaria prehispánica, invaluable herencia ancestral". http://www.jornada.unam.mx/2012/11/20/espectaculos/a09n1esp
} 
not be complete without Abigail Mendoza La Alquimista de los Sabores (the charmer of tastes), grinding maize - Mexico's most important heritage food - on a metate.

\section{REFERENCES}

Babb, F. E. (2010). The Tourism Encounter. Fashioning Latin American Nations and Histories. Stanford, CA: Stanford University Press.

Berger, D., Grant Wood, A. (eds.). (2010). Holiday in Mexico. Critical Reflections on Tourism and Tourist Encounters. Durham, NC: Duke University Press. https://doi.org/10.1215/9780822391265

Bonfil Batalla, G. (1996). Mexico Profundo: Reclaiming a Civilization. Austin: Texas University Press.

Brulotte R. L. (2012). Between Art and Artifact: Archaeological Replicas and Cultural Production in Oaxaca, Mexico. University of Texas Press.

Brulotte, R. L., Di Giovine M.A. (2014). Edible Identities: Food as Cultural Heritage. Farnham, United Kingdom: Ashgate.

Brulotte, R. L., Starkman, A. (2014). Caldo de Piedra and Claiming Pre-Hispanic Cuisine as Cultural Heritage. In R. L. Brulotte, M. A. Di Giovine (eds.), Edible Identities: Food as Cultural Heritage (pp. 109-124). Farnham, United Kingdom: Ashgate.

Brumann, C. (2014). Heritage agnosticism: a third path for the study of cultural heritage. Social Anthropology, 2(22), pp. 173-188. https://doi.org/10.1111/1469-8676.12068

Camacho, J. (2014). Una cocina exprés. Cómo se cocina una política pública de patrimonio culinario. In M. Chaves, M. Montenegro, M. Zambrano (eds.), El valor del patrimonio: mercado, políticas culturales y agenciamientos sociales (pp. 169-200). Bogotá, Colombia: ICANH.

Counihan, C. M. (2009). A Tortilla is Like Life. Food and Culture in the San Luis Valley of Colorado. Austin: University of Texas Press.

Christie, M. E. (2008). Kitchenspace. Women, Fiestas and Everyday Life in Central Mexico. Austin: Texas University Press.

Croucher, S. (2009). Migrants of Privilege: The Political Transnationalism of Americans in Mexico. Identities. Global Studies in Culture and Power, 16(4): pp. 463-491. https://doi.org/10.1080/10702890903020984

Friedensolm, D. (2001). Chapulines, Mole and Pozole. Mexican Cuisine and the Gringa Imagination. In S. A. Inness (ed.), Pilaf, Pozole, and Pad Thai: American Women and Ethnic Food (pp. 165-173). Amherst: University of Massachusetts Press.

Gagnier, M. J. (2005). Oaxaca Celebration. Family, Food, and Fiestas in Teotitlán. Santa Fe: Museum of New Mexico Press.

Gálvez, A. (2018). Eating NAFTA. Trade, Food Policies and the Destruction of Mexico. Oakland: University of California Press. https://doi.org/10.1525/california/9780520291805.001.0001

Garza Zepeda, M. (2016). Insurrección, fiesta y construcción de otro mundo en las luchas de la APPO. Mexico City, Mexico: Juan Pablos Editor/UABJO. 
Geyzen, A. (2015). Food Studies and the Heritage Turn: A Conceptual Repertoire. Food and History 2(12), 67-96. https://doi.org/10.1484/J.FOOD.5.108963

Goertzen, C. (2010). Tradition, Tourism and Political Ferment in Oaxaca. Jackson: University Press of Mississippi. https://doi.org/10.14325/mississippi/9781604737967.001.0001

González, R. J. (2014). Manufacturing Food Insecurity in Oaxaca, Mexico. In R. Stryker, R. J. González (eds.), Up, Down and Sideways: Anthropologists Trace the Pathways of Power (pp. 107-126). New York, NY: Berghahn Books.

Hryciuk, R. E. (2017). Mothering for neoliberal times. Mazahua women, poverty and the cultural politics of development in Central Mexico. Polish Sociological Review, 4(200), pp. 523-543.

Hryciuk, R. E. (2018). Tortilla Tour. Culinary Tourism in Globalized Oaxaca, Southern Mexico [in Polish]. Sociological Studies, 4(231), pp. 149-173.

Kastelein, B. (2010). The Beach and Beyond. In D. Berger, A. Grant Wood (eds.), Holiday in Mexico. Critical Reflections on Tourism and Tourist Encounters (pp. 320-374). Durham, NC: Duke University Press.

Kymlicka, W. (2013). Neoliberal multiculturalism? In P. A. Hall, M. Lamont (eds.), Social Resilience in the Neoliberal Era (pp. 99-125). Cambridge, United Kingdom: Cambridge University Press. https://doi.org/10.1017/CBO9781139542425.007

Long, L. M. (2004). Culinary Tourism: A Folkloric Perspective on Eating and Otherness. In L. M. Long (ed.), Culinary Tourism (pp. 20-49). Lexington, KY: University Press of Kentucky.

Martínez de Aguilar, K. (2014). Abigail Mendoza. Mujeres 12(144), pp. 30-32.

Matta, R. (2016). Food incursions into global heritage: Peruvian cuisine's slippery road to UNESCO. Social Anthropology, 24(3), pp. 338-352. https://doi.org/10.1111/14698676.12300

Matta, R. (2019). Mexico's Ethnic Culinary Heritage and Cocineras Tradicionales. Food and Foodways 27(3), 211-231. https://doi.org/10.1080/07409710.2019.1646481

McLean, A. (2012). The intersection of gender and food studies. In K. Albala (ed.), Routledge International Handbook of Food Studies (pp. 266-280). London, United Kingdom: Routledge.

Núñez Miranda, C. S. (2011). DISHDAA’W. La palabra se entreteje en la comida infinita. La vida de Abigail Mendoza. Oaxaca, Mexico: Fundación Alfredo Harp Helú/Proveedora Escolar.

Pilcher, J. M. (2012). Planet Taco. A Global History of Mexican Food. New York, NY: Oxford University Press.

Pilcher, J. M. (2004). "From "Montezuma's Revenge" to "Mexican Truffle": Culinary Tourism across the Rio Grande.” In L. M. Long (ed.), Culinary Tourism (pp. 76-95). Lexington, KY: University Press of Kentucky.

Rockower, P. S. (2012). Recipes for Gastrodiplomacy. Place Branding and Public Diplomacy, 8(3), pp. 235-246. https://doi.org/10.1057/pb.2012.17

Salazar, N. B. (2012). Tourism imaginaries: a conceptual approach. Annals of Tourism Research, 39(2), pp. 863-882. https://doi.org/10.1016/j.annals.2011.10.004

Sammells, C. (2014). Haute Traditional Cuisines: How UNESCO's List of Intangible Heritage Links the Cosmopolitan to the Local. In R. L. Brulotte, M. A. Di Giovine (eds.), Edible 
Identities: Food as Cultural Heritage (pp. 141-157). Farnham, United Kingdom: Ashgate. https://doi.org/10.4324/9781315578781-10

Stanford, L. (2012). When the Marginal Becomes the Exotic: The Political of Culinary Tourism in Indigenous Communities in Rural Mexico. In E. Finns (ed.), Reimagining Marginalized Foods. Global Processes, Local Places (pp. 67-87). Tucson: The University of Arizona Press. https://doi.org/10.2307/j.ctt1814g4b.7

Stephen, L. (2005). Zapotec Women: Gender, Class, and Ethnicity in Globalized Oaxaca. Durham, NC: Duke University Press. https://doi.org/10.1215/9780822387510

Stephen, L. (2007). Transborder lives. Indigenous Oaxacans in Mexico, California and Oregon. Durham, NC: Duke University Press. https://doi.org/10.1215/9780822389965

Stephen, L. (2013). We Are the Face of Oaxaca. Testimony and Social Movement. Durham, NC: Duke University Press. https://doi.org/10.1215/9780822377504

Wood, W. W. (2008). Made in Mexico: Zapotec Weavers and the Global Ethnic Art Market. Bloomington: Indiana University Press.

Wynne, L. A. (2015). I Hate it! Tortilla-Making, Class and Women's Tastes in Rural Yucatan, Mexico. Food, Culture and Society 18(3), pp. 379-397. https://doi.org/10.1080/15528014.2015.1043104 